\title{
Reflections on the attainment of puberty in the rat: have circadian signals a role to play in its onset?
}

\author{
Pamela C. B. MacKinnon, E. Puig-Duran and R. Laynes \\ Department of Human Anatomy, University of Oxford, South Parks Road, Oxford OXI 3QX, U.K.
}

The control of the onset of puberty, or the ability to procreate successfully, is as little understood today as it was 10 or 20 years ago. However, with respect to the development of mechanisms subserving the production and regulation of sex cells in the rat, much new information has accrued over the past few years. Since puberty is characterized by the integration and synchronization of such mechanisms it may be profitable, as a start to this symposium, to collate and attempt to resynthesize some of the available data.

With regard to the male, the onset of puberty is difficult to determine precisely since the basic output of gonadotrophins is characteristically acyclic and the potential for reproductive behaviour, when adult, uninterrupted. In sharp contrast, puberty in the female is dramatic; it is marked by the abrupt onset of cyclic gonadotrophic output and periods of receptivity to the male which are normally restricted to oestrus. It is possible, therefore, that the various events on which adult reproductive activity depends may be different in the two sexes.

Before outlining these events it is worth remembering that Harris \& Jacobsohn (1952), from the results of a classical experiment in which pituitary tissue from immature rats was grafted beneath the median eminence of hypophysectomized adult females and found to sustain full reproductive activity, suggested that mechanisms initiating and maintaining reproductive activity reside primarily in the brain.

\section{Serum gonadotrophin profiles during development}

Serum prolactin, FSH and LH concentrations during development in male and female rats (Text-figs 1 and 2) have been measured with radioimmunoassay techniques in many different laboratories (e.g. Ojeda \& Ramirez, 1972; Meijs-Roelofs, Uilenbroek, Osman \& Welschen, 1973; Döhler \& Wuttke, 1974; MacKinnon, Mattock \& ter Haar, 1976).

Prolactin. It is generally agreed that serum prolactin concentrations in the male increase gradually from about 25 days of age to attain adult levels between 55 and 70 days. In the female, prolactin levels also increase slowly from about 20 days of age to a few days before vaginal opening (or first oestrus), after which a noticeable increase occurs. It is unclear, however, whether the prepubertal increase is significant with respect to the onset of puberty, as suggested by Wuttke, Döhler \& Gelato (1976), or is due to inadvertent inclusion of rats in first pro-oestrus. Certainly, when the first day of pro-oestrus is reached, a preovulatory prolactin surge of adult dimensions occurs in the afternoon (Meijs-Roelofs, Uilenbroek, de Greef, de Jong \& Kramer, 1975; Parker \& Mahesh, 1976; Ojeda, Wheaton, Jameson \& McCann, 1976).

$F S H$. There is also general agreement with regard to serum FSH concentrations. In the neonatal male they are lower than in the adult but an increase occurs between 20 and 45 days of age, after which there is a drop to adult levels. In the female, neonatal levels are high in comparison with those of the adult; they increase between 7 and 25 days of age and then return to adult dioestrous values before vaginal opening. On the evening of first pro-oestrus the rise in FSH concentrations is equivalent to that observed during subsequent preovulatory surges (Meijs-Roelofs et al., 1975b; Parker \& Mahesh, 1976; Ojeda et al., 1976).

$L H$. There has been considerable disagreement between published results of serum $\mathrm{LH}$ concentrations during development. These discrepancies may have been due to the use of too few rats and/or to injudicious handling of the animals within $30 \mathrm{~min}$ of decapitation, since even mild stress prevents the occurrence of high LH values (MacKinnon et al., 1976). In our colony, serum LH concentrations 

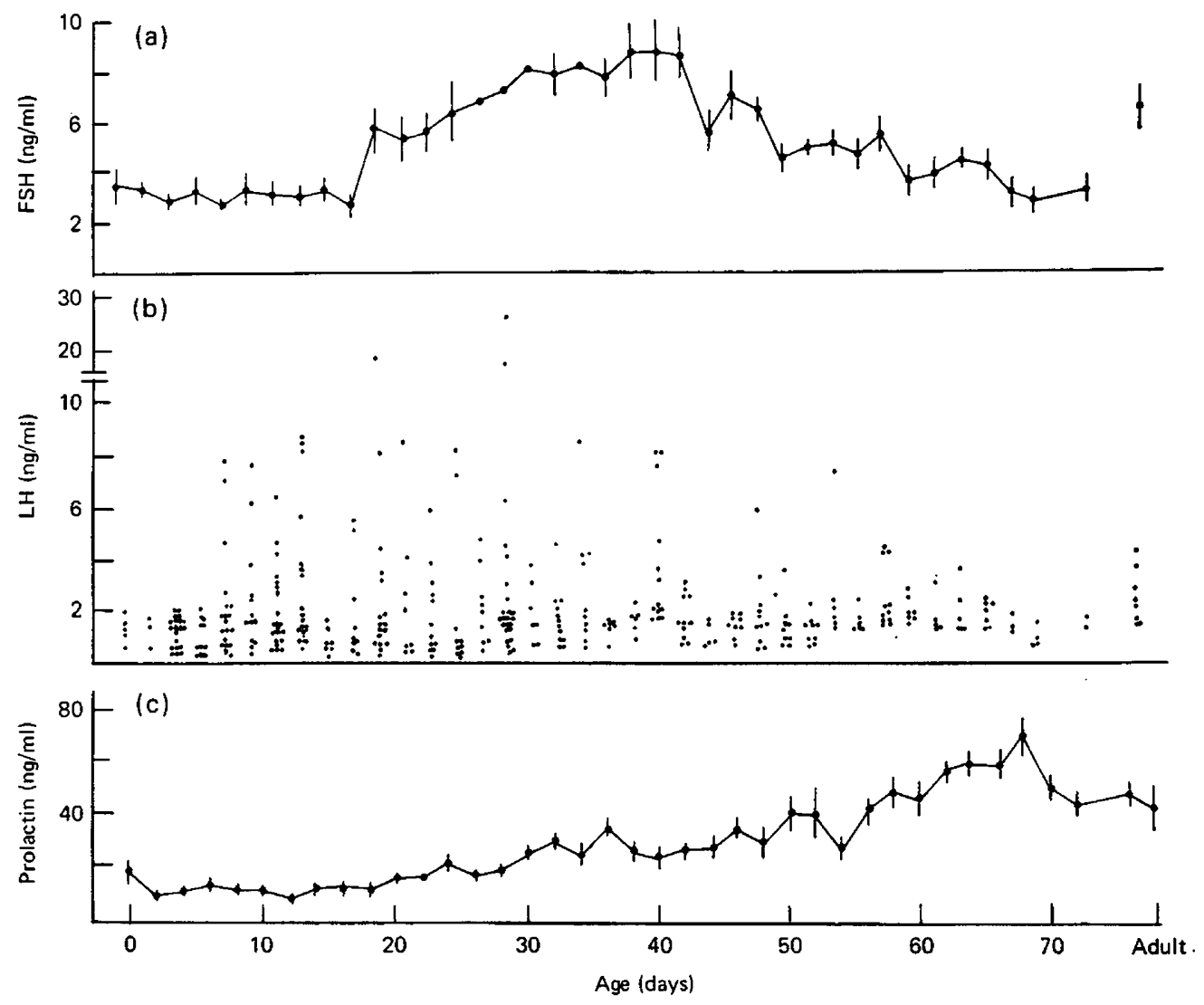

Text-fig. 1. Mean ( \pm s.e.m.) concentrations of (a) FSH, (b) LH and (c) prolactin in the serum of male rats (10/group) killed at 2-day intervals throughout development. From MacKinnon et al., 1976.

in the male are mostly low throughout development although very high levels are found in about $4 \%$ of the animals. These high levels are attributable to episodic LH releases which last about $1 \mathrm{~h}$ and may occur at any time of day (MacKinnon \& Mattock, 1976). In the female, LH levels are also basically low throughout development although high levels have been recorded in $7 \%$ of animals. High LH values are not accompanied by raised FSH or prolactin concentrations; furthermore they can be suppressed by oestrogen treatment (P. C. B. MacKinnon \& J. Mattock, unpublished observations) and are therefore unlikely to represent a true LH response to an oestrogen stimulus ('positive feedback'). These findings are not commensurate with those of Wuttke et al. (1976) who reported a suppression of episodic LH release after injection of antibodies to oestrogen. It is possible, however, that the stress of multiple injections rather than the antibody itself caused the disappearance of episodic $\mathrm{LH}$ release. On the evening of first pro-oestrus an LH surge of adult dimensions precedes ovulation (Meijs-Roelofs, de Greef \& Uilenbroek, 1975a; Parker \& Mahesh, 1976; Ojeda et al., 1976).

\section{Gonads and gonadal secretions during development}

Male testicular weight, relative to body weight, increases from about 20 days of age to reach a plateau between 40 and 80 days (Ewing, Means, Beames \& Montgomery, 1966; Desjardins, MacMillan \& Hafs, 1968). This is consistent with the testicular histology which shows a progressive increase in both the width and length of seminiferous tubules from 20 days to adulthood (Krueger, Hodgen $\&$ Sherins, 


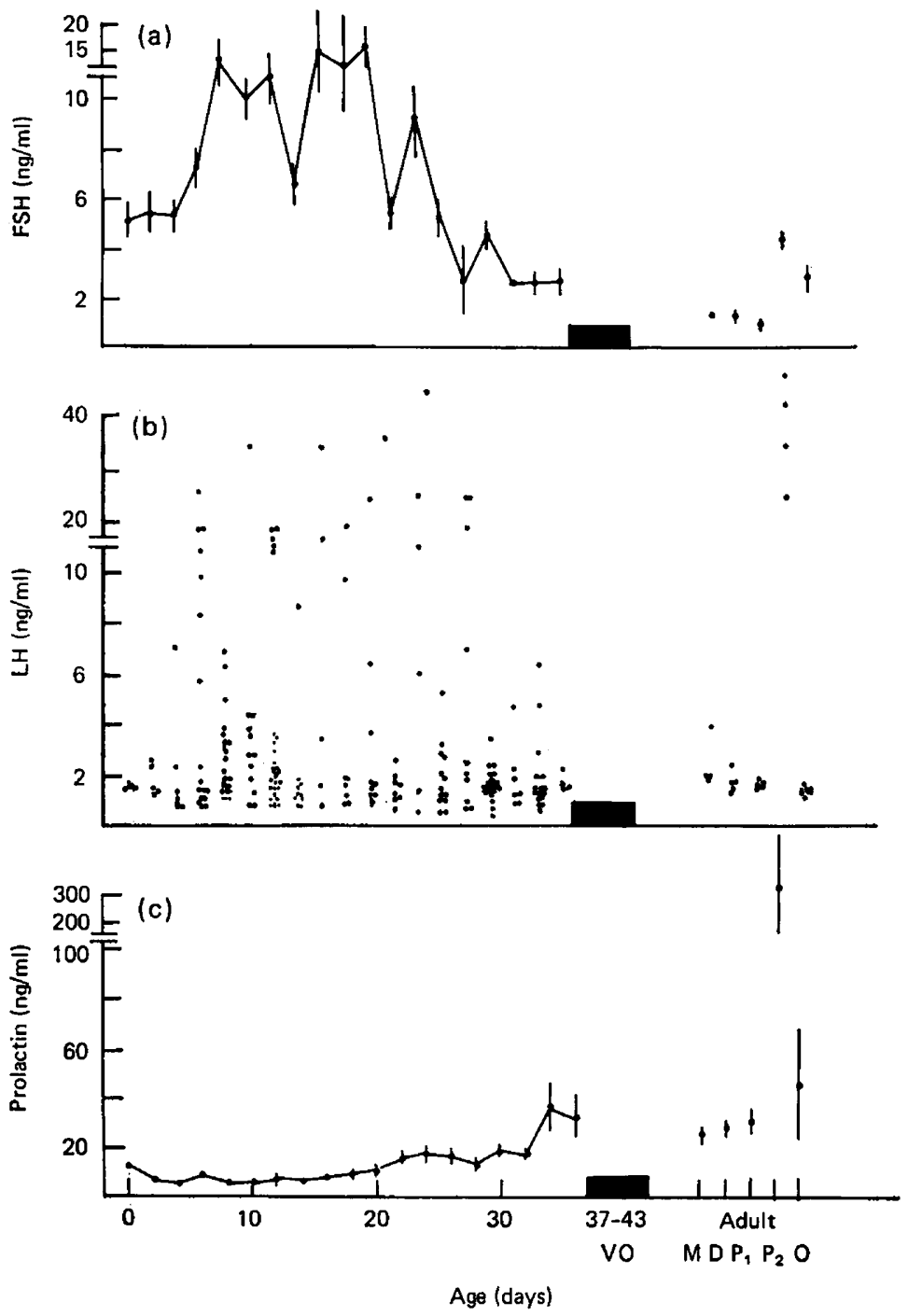

Text-fig. 2. Mean ( \pm s.e.m.) concentrations of (a) FSH, (b) LH and (c) prolactin in the serum of female rats (10/group) killed at 2-day intervals throughout development. VO= vaginal opening; $M=$ metoestrus; $D=$ dioestrus $; P_{1}=$ a.m. of pro-oestrus; $P_{2}=$ p.m. of pro-oestrus $; O=$ oestrus. From MacKinnon et al., 1976.

1974; de Jong \& Sharpe, 1977). The number of Sertoli cells and spermatogonia increases rapidly from about $20-40$ days, spermatids increase equally rapidly from 25 to 75 days, and mature spermatozoa are found in the reproductive tract from the age of about 50 days (Clermont \& Perey, 1957; Clegg, 1960; Swerdloff, Walsh, Jacobs \& Odell, 1971; de Jong \& Sharpe, 1977).

In the young rat, as in the guinea-pig (Becher \& Snipes, 1968) and the bull (Lindner \& Mann, 1960), androstenedione is secreted in larger amounts by the testis than is testosterone (Nayfeh \& Baggett, 1966; Ficher \& Steinberger, 1971; Moger, 1975). This is apparently due to the ability of testicular tissue in the young rat, especially between 20 and 30 days of age, to convert testosterone precursors preferentially to $5 \alpha$-reduced androgens, e.g. $5 \alpha$-androstan-3 $\alpha, 17 \beta$-diol (Coffey, French \& Nayfeh, 1971; Ficher \& Steinberger, 1971; Moger \& Armstrong, 1974). However, at about 40 days, and as maturation proceeds, testicular steroid metabolism changes and testosterone output rises 


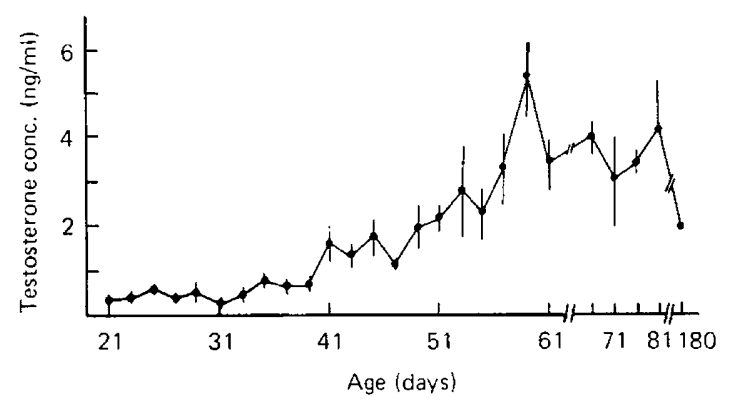

Text-fig. 3. Mean ( \pm s.e.m.) plasma testosterone concentrations in male rats (6/group) killed at 2-day intervals throughout development. From de Jong \& Sharpe, 1977.

(Text-fig. 3) relative to androstenedione; this event is accompanied by an increase in weight of the seminal vesicles and the ventral prostate gland.

De Jong \& Sharpe (1977), in a study of a possible correlation between data on spermatogenesis and hormone values, concluded that no such quantitative relationship existed in the young rat. Nevertheless, in the 50-day and older rats, greater numbers of spermatogenic cells were found at a time when plasma testosterone levels were increasing. Since the number of A-type spermatogonia per rat remained unchanged it was suggested that testosterone might increase the yield of the different mitotic and meiotic divisions; the effect was considered to be indirect and probably mediated by the Sertoli cell (see Lyon, Glenister \& Lamoureux, 1975).

With regard to testicular responsiveness to gonadotrophins during development, Odell \& Swerdloff (1976) observed that when hypophysectomized immature rats were injected 5 days after operation with $\mathrm{LH}$, neither plasma testosterone levels nor prostatic weight were increased, although similarly treated hypophysectomized adults showed a marked response to LH. However, the lack of responsiveness of the immature testis to LH could be overcome by prior administration of FSH. From the results of a further series of experiments, Odell \& Swerdloff (1976) suggested that the priming action of FSH on the testes was dependent on the promotion of $\mathrm{LH}$ receptors. Subsequent work showed that numbers of LH receptors, as assessed by the Leidenberger \& Reichert (1972) technique with Scatchard-plot analyses, were significantly increased after FSH treatment of hypophysectomized immature animals. Since serum FSH concentrations in the developing rat increase markedly between about 20 and 40 days of age, it was pertinent that testicular LH receptors in intact rats of different age increased progressively with maturation.

Ovarian weight, relative to body weight, increases slowly to about 20 days of age and then rises more rapidly to attain a plateau at about 40 days. Work on the developing mouse ovary has shown that around the time of birth all oocytes are in the resting prophase of first meiosis and enclosed in small follicles. Soon after birth certain follicles begin to grow; this growth of follicles can occur at any age (Peters, 1976) although the numbers doing so may be dissimilar (Pedersen, 1972). It was generally considered that before maturation follicles grew to a certain size and that under the influence of FSH a certain number were recruited for ovulation (Welschen, 1973; Greenwald, 1974). However, although many follicles are seen in the late stages of development (Jones \& Krohn, 1961; Gates, 1971) only a small number ovulate (Ingram, 1962; Edwards et al., 1977; Rowlands \& Weir, 1977; Weir \& Rowlands, 1977). An investigation of the effects of PMSG treatment on immature rats showed that, rather than increasing the numbers of large follicles, the hormone altered the balance between large and atretic follicles (Peters, Byskov, Lintern-Moore, Faber \& Anderson, 1973). These results led Peters (1976) to suggest that increased levels of FSH during development caused a decrease in the frequency of atretic follicles. This hypothesis was supported by data from experiments with ovarian tissue in vitro (McNatty, Bennie, Hunter \& McNeilly, 1976); maintenance of granulosa cells and prevention of atresia was found to be directly attributable to the presence of FSH in the culture medium. Further studies on the hormonal content of human Graafian follicular fluid (McNatty, Hunter, 
McNeilly \& Sawers, 1975) supported the previous findings and showed that an increase in FSH stimulated the granulosa cells to secrete oestradiol which in turn affected the growth of subsequent follicles (Baird, Baker, McNatty \& Neal, 1975).

It is reasonable to suppose, therefore, that the high serum FSH concentrations which are found in the developing rat between 7 and 25 days of age may prevent follicular atresia and stimulate the production of oestradiol from the granulosa cells. If this is so, then plasma oestradiol levels might be expected to rise after about 20 days of age, especially as uterine weight increases at this time. But apparently this is not the case since total plasma oestrogen levels in the young rat are high (Text-fig. 4), whereas after 21 days of age values decrease and remain consistently low until the first preovulatory rise (Cheng \& Johnson, 1974; Meijs-Roelofs et al., 1975b; Ojeda et al., 1976). The serum oestrogen profile is therefore paradoxical when viewed against the high serum FSH levels in the developing female rat. However, an explanation may lie in the presence of an oestrogen-binding protein (alphafetoprotein; AFP) in the plasma of neonatal and infant rats (Nunez, Engelmann, Benassayag \& Jayle, 1971; Raynaud, Mercier-Bodard \& Baulieu, 1971) which sequesters much of the circulating oestrogen (Text-fig. 4). Between 5 and 18 days of age $<1 \%$ of total serum oestradiol is unbound, at 21-25 days the percentage unbound levels increase and by 28 days they are $>4 \%$ and not significantly different from the values observed in the adult animal (Puig-Duran, Greenstein \& MacKinnon, 1977). Biological activity of the steroid is likely to be confined to the unbound fraction (Hoffman, Forbes \& Westphal, 1969; Vermeulen \& Verdonck, 1972) and therefore low oestrogen levels in the young rat may be responsible for high FSH levels because of the lack of negative feedback. That this is a likely possibility was suggested by the high FSH levels which occurred after i.v. injection of oestrogenbinding protein to 21- to 23-day-old animals (Puig-Duran et al., 1977). As a corollary, the fall in serum

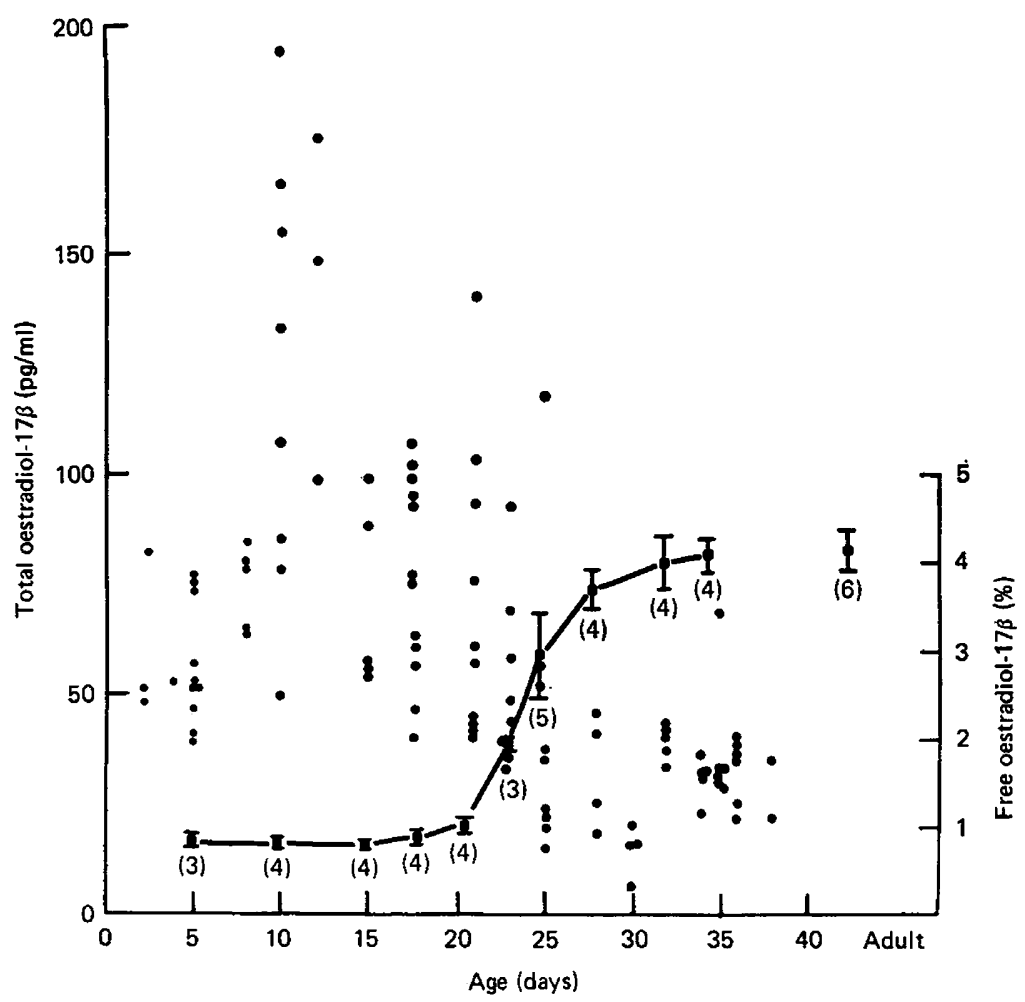

Text-fig. 4. Serum concentrations of oestradiol-17 $\beta$ in female rats throughout development. $\bullet$, Mean of duplicate measurements of total oestradiol $-17 \beta ; 0$, mean \pm s.e.m. (no. of animals in parentheses) values for the $\%$ of free (unbound) oestradiol-17 $\beta$. 
FSH concentrations that takes place after Day 25 is likely to be accounted for by the increasing percentage of unbound oestrogen.

With regard to ovarian sensitivity there is evidence to suggest that rising oestrogen values cause an increase in granulosa cells and thus an overall increase in FSH receptors per ovary (Louvet \& Vaitukaitis, 1976). Furthermore, as in the male, FSH appears to increase the numbers of LH receptors per ovary (Odell \& Swerdloff, 1976), while other work has shown that FSH in the presence of oestrogen increases the numbers of LH receptors on each granulosa cell (Richards et al., 1976).

Serum progesterone concentrations, which in the immature animals may be secreted both by the adrenal gland (Ramaley \& Bartosik, 1974) and the ovary (Meijs-Roelofs et al., 1975a), are low until about 10 days of age, after which they increase steadily until about the time of puberty (Döhler \& Wuttke, 1974). It has been suggested that the $5 \alpha$-reduced metabolite of testosterone, $5 \alpha$-androstane$3 \beta, 17 \beta$-diol, is of particular significance to the onset of puberty because daily injections of the hormone lead to early vaginal opening (Eckstein, 1976). However, if this premise is correct then it is strange that although the hormone is present in relatively high concentrations in the plasma of the young animal, it disappears from circulation at 26 days of age, i.e. 10 days or more before the onset of puberty.

\section{Central mechanisms}

\section{Pituitary sensitivity}

In immature male rats of different ages, the magnitude and pattern of the LH response to gonadotrophin-releasing hormone (GnRH) appears to be similar (Swerdloff \& Odell, 1974). Although, in comparison with the adult, the immature rat releases a greater amount of FSH in response to Gn-RH, the ratio of LH: FSH in all groups is $>1$.

In immature female rats, the response to a purified LH-RH preparation was greatest in 15- and 25-day-old animals and lowest at 35 days (Debeljuk, Arimura \& Schally, 1972). The possibility that the enhanced FSH response in the younger animals might be steroid-mediated was suggested by the observation that ovariectomy at 10 days of age abolished the GnRH-induced FSH response at 15 days (Ojeda, Jameson \& McCann, 1977). The response could be restored by injections of dihydrotestosterone, but not by oestradiol or testosterone treatment. We have recently obtained similar results with our Wistar rats.

\section{Negative feedback}

Brain-pituitary mechanisms associated with the negative feedback effects of steroids on gonadotrophin output are functional in male and female rats at a very early age (Goldman, Grazia, Kamberi \& Porter, 1971; Ojeda \& Ramirez, 1972; Meijs-Roelofs et al., 1973). In the 10-day and older rat, LH and FSH levels rise steeply within $2 \mathrm{~h}$ of castration and after about 5 days continue to increase (Swerdloff et al., 1971). In the neonatal and infant female the gonadotrophin response to gonadectomy is more sluggish, in timing and output, than that in the male, but this may partly be accounted for by the already high levels of FSH in the intact infant female, which in turn appear to depend on low levels of unbound oestrogen.

On the basis of early findings (Donovan \& van der Werff ten Bosch, 1959) and those obtained from steroid replacement studies after gonadectomy (Ojeda \& Ramirez, 1973; Steele \& Weisz, 1974), the concept grew that as maturity progressed there was a decrease in sensitivity of brain-pituitary mechanisms to negative feedback, and that this might in some way account for the onset of puberty. However, Odell \& Swerdloff (1976) have found that testosterone treatment, initiated on the day of castration, lowers serum LH concentrations equally well in 10- and 21-day-old as in 73-day-old males; the dose of testosterone required to lower post-castration FSH values was smaller in the youngest animals, although similar doses were required for 21 - and 75-day-old animals. These results do not support the 'decreasing sensitivity to steroid feedback' hypothesis for the onset of puberty. Furthermore, a consideration of the separate hormonal profiles during development also fails to provide any indication of a tendency for LH or FSH levels to rise over the period of puberty; an effect which might be expected if the hypothesis was to hold true. 


\section{Positive feedback}

Brain-pituitary mechanisms subserving the gonadotrophin response to an oestrogen stimulus are also fully developed and functional well before the occurrence of first oestrus (Caligaris, Astrada \& Taleisnik, 1972; Puig-Duran \& MacKinnon, 1978). A single injection (s.c.) of oestrogen at 12:00 h will cause an LH surge about 50-54 h later in 21-day-old (Text-fig. 5), though not in younger, rats. However, if the animals are first injected with oestrogen and then receive an injection of progesterone a few hours before the expected LH surge, the response can be obtained as early as 14 days of age (Puig-Duran \& MacKinnon, 1978). A surge of prolactin, occurring at the same time as the LH surge, can also be elicited by oestrogen treatment (Cheng \& Johnson, 1974) and can be shown at 9 days of age (Puig-Duran \& MacKinnon, 1978). The male rat is known to be unable to respond to a steroid stimulus with a release of gonadotrophins, although such a sexually differentiated response does not seem to hold true for the monkey (Karsch, Dierschke \& Knobil, 1973) or man (Stearns, Winter \& Faiman, 1973).

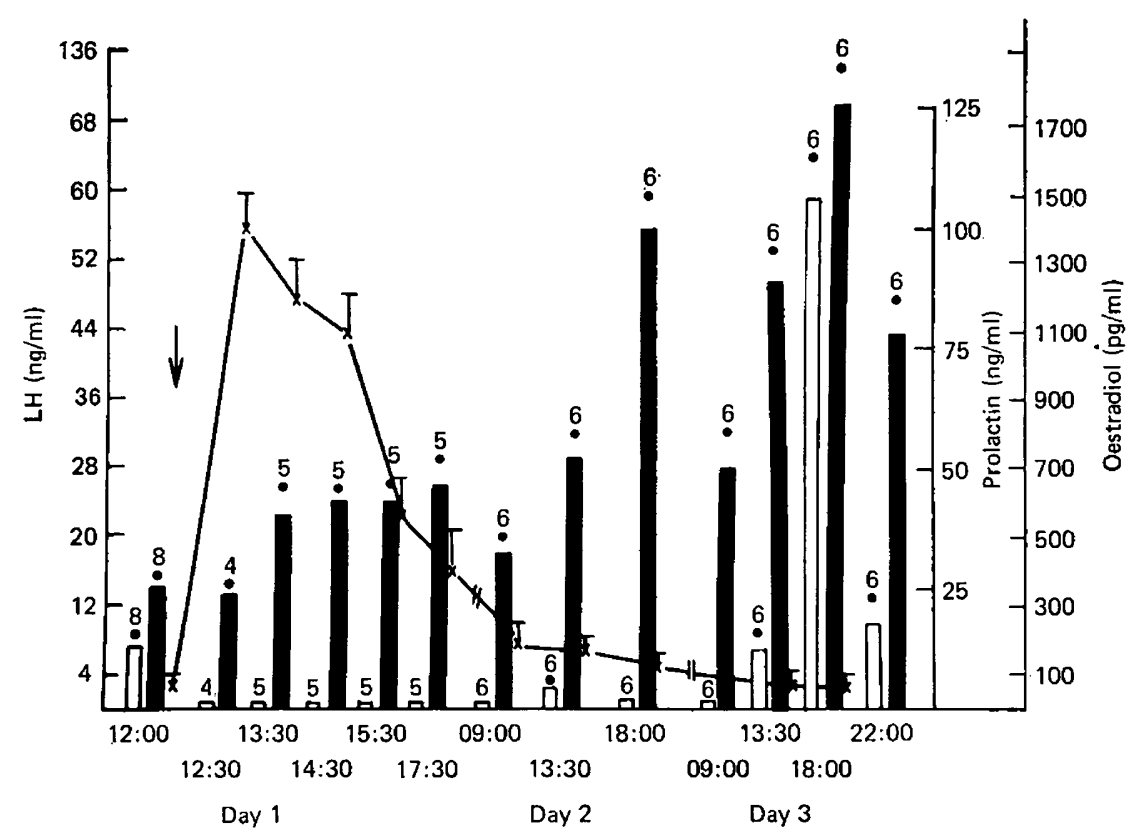

Text-fig. 5. Mean \pm s.e.m. ( or vertical bar) concentrations of LH (open columns), prolactin (solid columns) and oestradiol $(x)$ in 21-day-old female rats injected with $1 \mu \mathrm{g}$ oestradiol benzoate (arrow) and killed at the times shown. The numbers against the columns indicate the number of animals. From Puig-Duran \& MacKinnon, 1978.

\section{Has the 'daily signal' a role to play in the onset of puberty?}

As far as the female is concerned it is quite clear that at least 10 days before the expected onset of puberty the ovary can be stimulated to ovulate, and will continue to cycle, either directly by PMSG treatment (see Ying \& Greep, 1973) or indirectly by oestrogen treatment (see Döcke \& Dorner, 1974) or by stimulation of the preoptic area (Meijs-Roelofs, 1972). Moreover, the anterior pituitary cells are fully responsive to GnRH and negative and positive feedback mechanisms are fully developed and functional well before regular oestrous cycles are initiated. Is it possible then that the trigger to the onset of regular cyclicity is a signal which synchronizes evening surges of gonadotrophins and other relevant hormones in order to stimulate the production of oestrogen and ovulation a few days later?

Everett \& Sawyer (1950) were the first to demonstrate the dependence of the rat oestrous cycle on a 'daily signal'; they found that if a neural event ('critical period'), lasting about $2 \mathrm{~h}$ on the afternoon 
of pro-oestrus and linked with the light: dark cycle (Critchlow, 1963), was prevented by means of a central nervous depressant, then ovulation was delayed for $24 \mathrm{~h}$. Recently it has been shown that the integrity of the suprachiasmatic nucleus is essential not only for circadian rhythmicity but also for the elicitation of the LH surge (Bishop, Kalra, Fawcett, Krulich \& McCann, 1972; Coen \& MacKinnon, 1976). It is also worth noting that retino-hypothalamic connections to the suprachiasmatic nucleus, which may be responsible for the light entrainment of circadian rhythms (Moore \& Eichler, 1976), can be demonstrated at about 18 days of age in the female rat, i.e. the time at which circadian rhythms of corticosterone output (Ader, 1969; Campbell \& Ramaley, 1974) and a positive oestrogen feedback response (Puig-Duran \& MacKinnon, 1978) are becoming established.

It seems possible, therefore, that circadian signals may have a role to play in the onset of puberty and we have made some preliminary observations with Wistar rats in which vaginal opening and first oestrus occur between 37 and 45 days of age. Groups of 10-, 28-, 32-, 34- and 36-day-old female rats were decapitated at intervals over a 24-h period and blood samples were obtained from the trunk for measurement of serum $\mathrm{LH}, \mathrm{FSH}$, prolactin and corticosterone concentrations. The samples were centrifuged and the sera kept at $-30^{\circ} \mathrm{C}$ until they were assayed. The gonadotrophins were measured by double-antibody radioimmunoassays which have been previously described (MacKinnon et al., 1976); corticosterone values were also measured by the radioimmunoassay described by Corker, Naftolin \& Richards (1971).

The results (Text-figs 6 and 7) showed that each of the hormones, with the exception of $\mathrm{LH}$, had an apparent circadian rhythm of output. The basal values of LH were low, although some very high levels, attributable to episodic release (MacKinnon et al., 1976), were recorded in each of the age groups. FSH output showed a daily rhythm with peak levels in 28-day-old rats occurring in the morning; the morning levels diminished progressively as prepubertal age increased. There was a clear daily rhythm of serum prolactin concentrations in 34- and 36-day-old rats, with peak levels occurring between 15:00 and 18:00 h, but not in the younger animals. Serum corticosterone concentrations showed a circadian output at 28 days of age, although the amplitude of the rhythm was small in comparison with that observed at 36 days; both groups, however, showed peak levels between 15:00 and 18:00 $\mathrm{h}$. In the 32- and 34-day-old groups the rhythm seemed to have disappeared-an unexpected

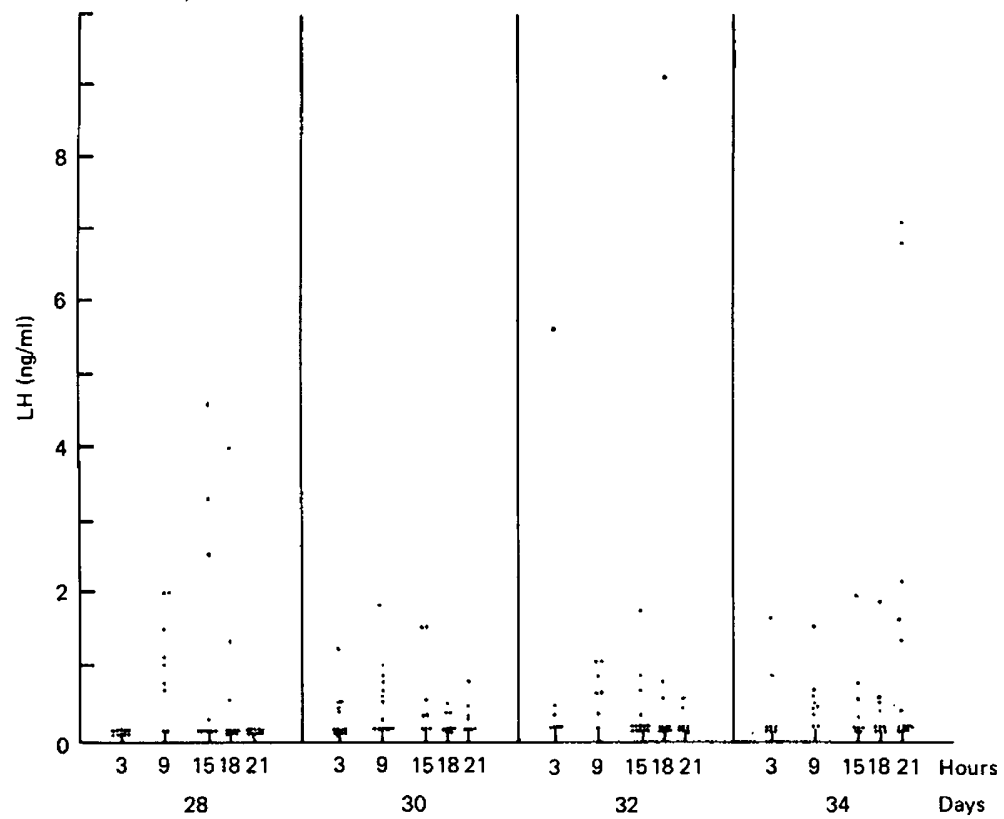

Text-fig. 6. Individual serum LH concentrations in female rats (10 at each age and time) killed at 03:00, $09: 00,15: 00,18: 00$ or $21: 00 \mathrm{~h}$. 


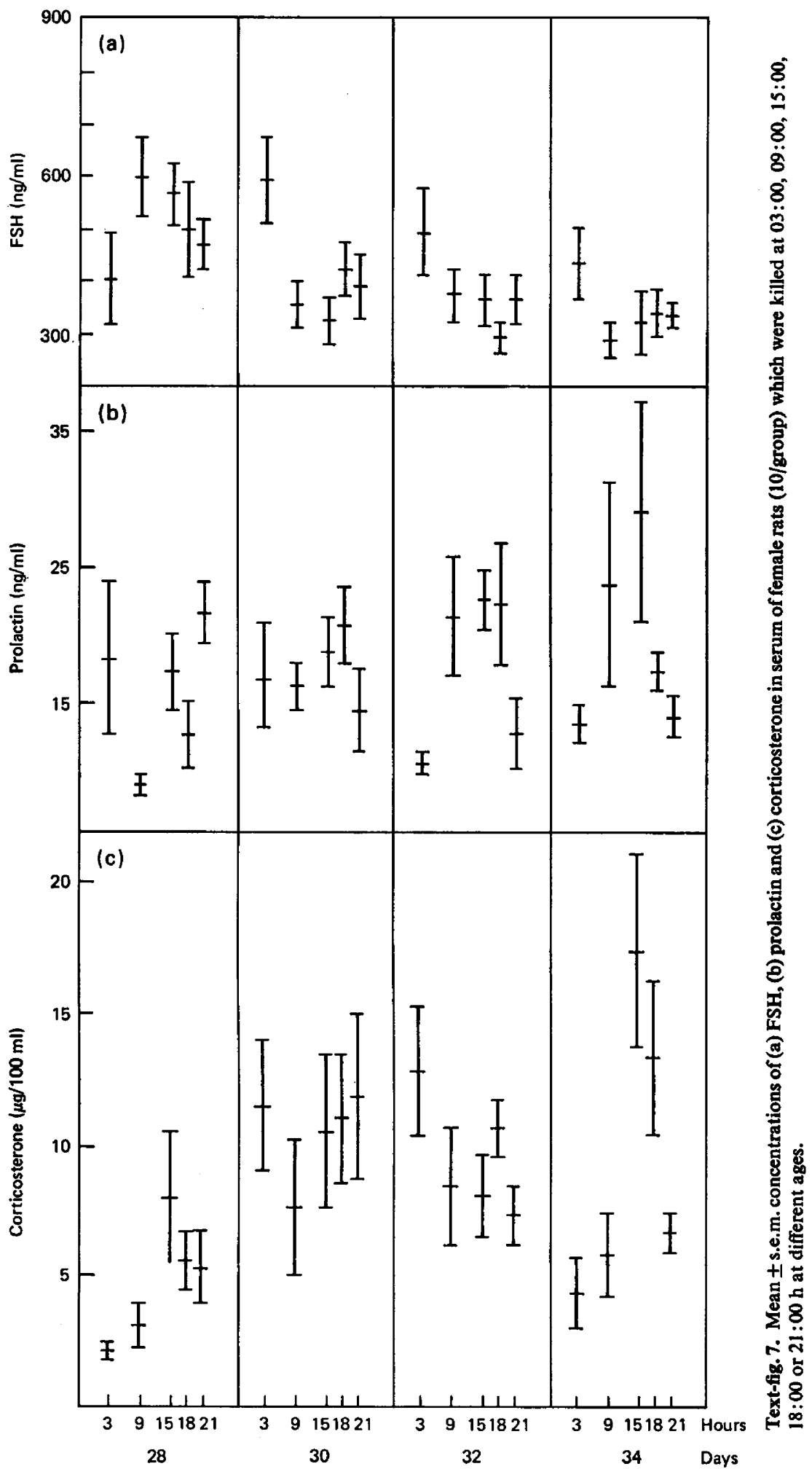


'scrambling' effect which has also been observed by Dr J. Ramaley in a different strain of rats (personal communication).

From these preliminary results it would appear that in the female rat changes in the phase and/or alterations in the amplitude of circadian rhythms of hormonal output take place in the prepubertal period. Such an effect might enable peak levels of pituitary hormones to become synchronized in the late afternoon with an episodic release of LH and thus result in final maturation of ovarian follicles and a preovulatory increase in oestrogen.

\section{Conclusions}

In the developing male rat, changes in testicular steroid synthesis take place which ensure a preferential output of testosterone. In addition, raised serum FSH concentrations, controlled by steroid feedback, appear to increase testicular receptivity to LH by increasing the numbers of LH receptors. Testosterone levels therefore increase, the reproductive tract enlarges and spermatogenesis is enhanced. A further effect of testosterone, or its metabolites, is to stimulate central nervous mechanisms concerned with sexual and other patterns of behaviour (Davidson \& Levine, 1972). The onset of puberty in the male therefore occurs as a gradual sequence of events leading to the production of viable spermatozoa and the enhancement of previously learned behavioural patterns, both of which are essential for successful procreation.

In the female, the occurrence of first oestrus and ovulation is a sudden event. Ovarian and pituitary tissue and the recognized neural mechanisms subserving the preovulatory hormonal events and female patterns of sexual behaviour are fully developed and functional many days before regular oestrous cycles are initiated. Preliminary observations suggest that the onset of puberty in the rat may occur as a result of changes in the amplitude and phase of the circadian rhythms of hormonal output which take place in the prepubertal period. Such changes may enable peak levels of pituitary hormones to become synchronized in the late afternoon and so lead to stimulation of mature ovarian follicles to secrete the first preovulatory rise of oestrogen.

\section{References}

ADER, R. (1969) Early experiences accelerate maturation of the 24-hour adrenocortical rhythm. Science, N.Y. 163, $1225-1226$.

Baird, D.T., Baker, T.G., McNatty, K.P. \& Neal, P. (1975) Relationship between the secretion of the corpus luteum to the length of the follicular phase in the ovarian cycle. J. Reprod. Fert. 45, 611-619.

Becher, W.G. \& SNIPes, C.A. (1968) Shift with age in steady-state concentrations of androstenedione and testosterone in incubations of guinea-pig testis. Biochem. J. 107, 35-40.

Bishop, W., KalRa, P.S., Fawcett, C.P., Krulich, L. \& MCCANN, S.M. (1972) The effects of hypothalamic lesions on the release of gonadotrophins and prolactin in response to estrogen and progesterone treatment in female rats. Endocrinology 91, 1404-1410.

Caligaris, L., Astrada, J.J. \& Taleisnik, S. (1972) Influence of age on the release of luteinizing hormone induced by oestrogen and progesterone in immature rats. J. Endocr. 55, 97-103.

Campbell, C.B.G. \& Ramaley, J.A. (1974) Retinohypothalamic projections: correlation with onset of the adrenal rhythm in infant rats. Endocrinology 94, 1201-1204.
Cheng, H.C. \& Johnson, D.C. (1974) Temporal changes in serum estradiol and prolactin in immature rats given a single injection of estradiol benzoate. Steroids 24, 657-664.

Clegg, E.J. (1960) The age at which male rats become fertile. J. Reprod. Fert. 1, 119-120.

Clermont, Y. \& Perey, B. (1957) Quantitative study of the cell population of the seminiferous tubules in immature rats. Am. J. Anat. 100, 24l-267.

Coen, C. \& Mackinnon, P.C.B. (1976) Serotonin involvement in oestrogen-induced luteinizing hormone release in ovariectomised rats. $J$. Endocr. 71, $49 P-$ $50 P$.

Coffey, J.C., French, F.S. \& NAYfeh, S.N. (1971) Metabolism of progesterone by rat testicular homogenates. IV. Further studies of testosterone formation in immature testis in vitro. Endocrinology 89, 865-872.

Corker, C.S., Naftolin, F. \& Richards, M.R. (1971) An ultramicro protein binding method for the assay of corticosteroids in small volumes of plasma. $J$. Physiol., Lond. 218, 28P-29P.

Critchlow, V. (1963) The role of light in the neuroendocrine system. In Advances in Neuroendocrinology, pp. $377-402$. Ed. A. V. Nalbandov. University of Illinois Press, Urbana, Illinois. 
Davidson, J.M. \& Levine, S. (1972) Endocrine regulation of behavior. A. Rev. Physiol. 34, 375-408.

DebeljuK, L., Arimura, A. \& Schally, A.V. (1972) Pituitary responsiveness to LH-releasing hormone in intact female rats of different ages. Endocrinology 90, 1499-1502.

DE Jong, F.H. \& Sharpe, R.M. (1977) The onset and establishment of spermatogenesis in rats in relation to gonadotrophin and testosterone levels. J. Endocr. 75, 197-207

Desjardins, C., MacMillan, K.L. \& Hafs, H.D. (1968) Reproductive organ DNA and RNA of male and female rats from birth to 100 days of age. Anat. Rec. 161, 17-22.

DöCKE, F. \& DöRNER, G. (1974) Oestrogen and the control of gonadotrophin secretion in the immature rat. J. Endocr. 63, 285-298.

DöHLER, K.D. \& WuTtke, W. (1974) Serum LH, FSH, prolactin and progesterone from birth to puberty in female and male rats. Endocrinology 94, 1003-1008.

DONOVAN, B.T. \& VAN DER WERFF TEN BOSCH, J.J. (1959) The hypothalamus and sexual maturation in the rat. J. Physiol., Lond. 147, 78-92.

ECKsteIN, B. (1976) Androstanediols during sexual maturation: biosynthesis by the immature rat ovary in vitro and some biological effects. Annls Biol. anim. Biochim. Biophys. 16, 319-325.

Edwards, R.G., Fowler, R.E., Gore-Langton, R.E., Gosden, R.G., Jones, E.C., Readhead, C. \& STEPTOE, P.C. (1977) Normal and abnormal follicular growth in mouse, rat and human ovaries. J. Reprod. Fert. 51, 237-263.

EveretT, J.W. \& SAWYer, C.H. (1950) A 23-hour periodicity in the "LH release apparatus" of female rats, as disclosed by barbiturate sedation. Endocrinology 47, 198-218.

Ewing, L.L., Means, A.R., Beames, C.G., JR \& MONTGOMERY, R.D. (1966) Biochemical changes in rat testis during postnatal maturation. J. Reprod. Fert. 12, 295-307.

Ficher, M. \& Steinberger, E. (1971) In vitro progesterone metabolism by rat testicular tissue at different stages of development. Acta endocr., Copenh. 68, 285292.

GATES, A. (1971) Maximizing yield and developmental uniformity of eggs. In Methods in Mammalian Embryology, pp. 64-75. Ed. J. C. Daniel. W. H. Freeman \& Co., San Francisco.

Goldman, B.D., Grazia, Y.R., Kamberi, I.A. \& PORTER, J.C. (1971) Serum gonadotrophin concentrations in intact and castrated neonatal rats. Endocrinology 88, 771-776.

Greenwald, G.S. (1974) Role of FSH and LH in follicular development and ovulation in the hypothalamo-hypophyseal system. Ed. E. Knobil. In Handbook of Physiology, Section 7, Vol. 4, Part 1, pp. 293-323. Ed. E. Knobil. Am. Physiol. Soc., Washington, D.C.

HARRIS, G.W. \& JACOBSOHN, D. (1952) Functional grafts of the anterior pituitary gland. Proc. $R$. Soc. Lond. $B$ 139, 263-276.

Hoffman, W., Forbes, T.R. \& WestPhal, U. (1969) Biological inactivation of progesterone by interaction with corticosteroid-binding globulin and with albumin. Endocrinology 85, 778-781.

Ingram, D.L. (1962) Atresia. In The Ovary, 1st edn, Vol. 1, pp. 247-273. Ed. S. Zuckerman. Academic Press, New York.

JONES, E.C. \& KROHN, P.L. (1961) The relationship between age, numbers of oocytes and fertility in virgin and multiparous mice. J. Endocr. 12, 469-495.

Karsch, F.J., Dierschke, D.J. \& KNOBIL, E. (1973) Sexual differentiation of pituitary function : apparent difference between primates and rodents. Science, N. Y. 179, 484-486.

Krueger, P.M., Hodgen, G.D. \& Sherins, R.J. (1974) New evidence for the role of the Sertoli cell and spermatogonia in feedback control of FSH secretion in male rats. Endocrinology $95,955-962$.

LEIDENBERGER, F. \& REICHERT, L.E. (1972) Evaluation of a rat testis homogenate radioligand receptor assay for human pituitary LH. Endocrinology 91, 901-909.

LINDNER, H.R. \& MANN, T. (1960) Relationship between the content of androgenic steroids in the testes and the secretory activity of the seminal vesicles in the bull. J. Endocr. 21, 341-360.

LOUVET, J.-P. \& VAITUKaITIS, J.L. (1976) Induction of follicle-stimulating hormone (FSH) receptors in rat ovaries by oestrogen priming. Endocrinology $99,758-$ 764.

Lyon, M.F., Glenister, P.H. \& Lamoureux, M.L. (1975) Normal spermatozoa from androgen resistant germ cells of chimaeric mice and the role of androgen in spermatogenesis. Nature, Lond. 258, 620-622.

MacKinnon, P.C.B. \& Mattock, J. (1976) The effects of handling on episodic release of LH in immature rats. Annls Biol. anim. Biochim. Biophys. 16, 345-348.

MacKinnon, P.C.B., MatTock, J.M. \& TER HAAR, M.B. (1976) Serum gonadotrophin levels during development in male, female and androgenized female rats and the effect of general disturbance on high luteinizing hormone levels. J. Endocr. 70, 361371.

MCNatty, K.P., Hunter, W.M., MCNeilly, A.S. \& SAWERS, R.S. (1975) Changes in the concentration of pituitary steroid hormones in the follicle fluid of human Graafian follicles throughout the menstrual cycle. $J$. Endocr. 64, 555-571.

MCNatry, K.P., Bennie, J.G., Hunter, W.M. \& McNeilly, A.S. (1976) The effects of antibodies to human gonadotrophins on the viability and rate of progesterone secretion by human granulosa cells in tissue culture. In Physiological Effects of Immunity against Reproductive Hormones, pp. 41-66. Eds R. G. Edwards \& M. H. Johnson. Cambridge University Press.

MeIJs-Roelofs, H.M.A. (1972) Effect of electrical stimulation of the hypothalamus on gonadotrophin release and the onset of puberty. J. Endocr. 54, 277-284.

Meijs-Roelofs, H.M.A., Uilenbroek, J.Th.J., Osman, P. \& Welschen, R. (1973) Serum levels of gonadotrophins and follicular growth in prepubertal rats. In Development and Maturation of the Ovary, and its Functions, pp. 3-11, Ed. H. Peters. Excerpta Medica Int. Congr. Ser. No. 267, Amsterdam.

Meijs-Roelofs, H.M.A., DE GreeF, W.J. \& Uilenbroek, J.Th.J. (1975a) Plasma progesterone and its relation- 
ship to serum gonadotrophins in immature female rats. J. Endocr. 64, 329-336.

Meijs-Roelofs, H.M.A., Uilenbroek, J.Th.J., DE Greef, W.J., DE JoNG, F.H. \& KRAMER, P. (1975b) Gonadotrophin and steroid levels around the time of first ovulation in the rat. $J$. Endocr. 67, 275-282.

MOGER, W.H. (1975) Serum testosterone and luteinizing hormone concentrations in castrated immature rats treated with testosterone. J. Endocr. 67, 135-136.

Moger, W.H. \& ARMSTRong, D.T. (1974) Steroid metabolism by the immature rat testis. Can. J. Biochem. 52, 744-750.

MoORE, R.Y. \& EICHLER, V.B. (1976) Central neural mechanisms in diurnal rhythm regulation and neuroendocrine responses to light. Psychoneuroendocrinology 1, 265-279.

NAYFEH, S.N. \& BaggetT, B. (1966) Metabolism of progesterone by rat testicular homogenates. I. Isolation and identification of metabolites. Endocrinology 78, $460-470$.

Nunez, E., Engelmann, F., Benassayag, C. \& J Jyle, M.-F. (1971) Identification et purification preliminaire de la foeto-proteine liant les oestrogènes dans le serum des rats nouveau-nés. $C$. $r$. hebd. Séanc. Acad. Sci., Paris 273, 831-834.

Odell, W.D. \& SWERdLoff, R.S. (1976) Etiologies of sexual maturation. A model system based on the sexually maturing rat. Recent Prog. Horm. Res. 32, 245-288.

OJedA, S.R. \& Ramirez, V.D. (1972) Plasma levels of LH and FSH in maturing rats: response to hemigonadectomy. Endocrinology 90, 466-472.

OjedA, S.R. \& RAMIREZ, V.D. (1973) Short-term steroid treatment on plasma $\mathrm{LH}$ and FSH in castrated rats from birth to puberty. Neuroendocrinology 13,100114.

OJeda, S.R., Wheaton, J.E., Jameson, H.E. \& MCCanN, S.M. (1976) The onset of puberty in the female rat: changes in plasma prolactin, gonadotrophins, luteinizing hormone-releasing hormone and hypothalamic LH-RH content. Endocrinology 98, 630638.

OJeda, S.R., JAMeson, H.E. \& MCCANN, S.M. (1977) Developmental changes in pituitary responsiveness to $\mathbf{L H}-\mathbf{R H}$ in the female rat: ovarian-adrenal influence during the infantile period. Endocrinology 100, $440-451$.

PARKer, C.R. \& Mahesh, V.B. (1976) Hormonal events surrounding the natural onset of puberty in female rats. Biol. Reprod. 14, 347-353.

Pedersen, T. (1972) Follicle growth in the mouse ovary. In Oogenesis, pp. 361-376. Eds J. D. Biggers \& A. W. Schuetz. University Park Press, Baltimore.

Peters, H. (1976) The development and maturation of the ovary. Annls Biol. anim. Biochim. Biophys. 16, 271-278.

Peters, H., Byskov, A.G., Lintern-Moore, S., Faber, M. \& ANDERSon, M. (1973) The effect of gonado- trophin on follicle growth initiation in the neonatal mouse ovary. J. Reprod. Fert. 35, 139-141.

Puig-Duran, E. \& Mackinnon, P.C.B. (1978) A critical period for positive feedback in immature (21-day-old) rats. $J$. Endocr. (in press).

RAmaley, J.A. \& Bartosik, D. (1974) Rhythms of progesterone and corticosterone after PMS-induced puberty: effects of ovariectomy. Endocrinology 95, 1719-1725.

Raynaud, T.P., Mercier-Bodard, C. \& Baulieu, E.E. (1971) Rat estradiol binding plasma protein (EBP). Steroids 18, 767-788.

Richards, J.S., Ireland, J.J., RaO, M.C., Bernath, G.A., Midgley, A.R., JR \& Reichert, L.E. (1976) Ovarian follicular development in the rat: hormone receptor regulation by estradiol, follicle stimulating hormone and luteinizing hormone. Endocrinology 99, 1562-1570.

RoWLANDS, I.W. \& WElR, B.J. (1977) The ovarian cycle in vertebrates. In The Ovary, 2nd edn, Vol. 2, pp. 217273. Eds S. Zuckerman \& B. J. Weir. Academic Press, New York.

Stearns, E.L., Winter, J.S.D. \& Faiman, C. (1973) Positive feedback effect of progestin upon serum gonadotrophins in estrogen-primed castrate men. $J$. clin. Endocr. Metab. 37, 635-638.

Steele, R.E. \& Weisz, J. (1974) Changes in sensitivity of the estradiol-LH feedback system with puberty in the female rat. Endocrinology 95, 513-520.

SWerdloff, R.S. \& Odell, W.D. (1974) The role of the gonads in sexual maturation. In The Control of the Onset of Puberty, Ch. 11, pp. 313-341. Eds. M. M. Grumbach, G. D. Grave \& F. E. Mayer. Wiley, New York.

SWerdloff, R.S., Walsh, P.C., Jacobs, H.S. \& Odell, W.D. (1971) Serum LH and FSH during sexual maturation in the male rat: effect of castration and cryptorchidism. Endocrinology 88, 120-128.

Vermeulen, A. \& Verdonck, L. (1972) Some studies on the biological significance of free testosterone. $J$. Steroid Biochem. 3, 421-426.

WEIR, B.J. \& Rowlands, I.W. (1977) Ovulation and atresia. In The Ovary, 2nd edn, Vol. 1, pp. 265-301. Eds S. Zuckerman \& B. J. Weir. Academic Press, New York.

WELSCHEN, R. (1973) Amounts of gonadotrophins required for normal follicular growth in hypophysectomized adult rats. Acta endocr., Copenh. 72, 137155.

Wuttke, W., DöhleR, K.D. \& Gelato, M. (1976) Oestrogens and prolactin as possible regulators of puberty. J. Endocr. 68, 391-396.

YING, S.-Y. \& GREeP, R.O. (1973) Effect of gonadotrophins and steroids on the maturation of the female reproductive function. In The Development and Maturation of the Ovary and its Functions, pp. 181184. Ed. H. Peters. Excerpta Medica Int. Congr. Ser. No. 267, Amsterdam. 